\title{
PENGEMBANGAN MODEL KEMAMPUAN GENERIK MENULIS CERPEN \\ (STUDI CLASSROOM ETNOGRAPHY SISWA KELAS XI MAN 1 MATARAM)
}

\section{THE DEVELOPMENT OF LEARNING MODEL OF GENERIC SKILL IN WRITING SHORT STORIES}

(CLASSROOM ETHNOGRAPHY STUDY OF ELEVENT GRADERS OF SCIENCE X1 CLASS OF MAN 1 MATARAM)

\author{
Rabiyatul Adawiyah, Syukrina Rachmawati \\ Universitas Nachdlatul Wathan Mataram \\ email: rabiyatula@gmail.com, email: riena_ingez@yahoo.com
}

Diterima: 21 November 2015, Direvisi: 15 Desember 2015, Disetujui: 20 Desember 2015

\begin{abstract}
The purpose of this research is to describe the development of learning model with generic skill in writing short stories towards the improvement of students achievement. Learning process emphasis on the students to work in small groups and cooperate with each other in learning the lesson by implementing student centered approach. The method used is classroom etnography with the subject of elevent graders of science 2 of MAN 1 Mataram. The data were collected through observation, questionnaire, document, and interview. The result of the research showed that the development of learning model of generic skill have some advantages: time accuracy $76 \%$, cooperation 92\%, mativation $94 \%$, responsibility $74 \%$ and critical thinking $76 \%$. The result showed that the students' skill in writing short story was $94 \%$ which belonged to high category. This research can be concluded that learning process using the development of learning model of generic skill is better and can improve the quality of learning process and students work.
\end{abstract}

Keywords: The Development of Learning Model, generic skill, writing short story

Abstrak

Penelitian ini bertujuan untuk mendeskripsikan pengembangan model pembelajaran kemampuan generik dalam materi menulis cerpen terhadap peningkatan hasil belajar siswa. Pembelajaran menekankan pada peserta didik untuk bekerja dalam kelompok kecil untuk saling membantu satu sama lainnya dalam mempelajari materi pelajaran dengan berpusat pada siswa (student centered). Metode yang digunakan yaitu Classroom etnograpy dengan subyek satu kelas yaitu kelas XI IPA 2 MAN 1 Mataram. Data dikumpulkan melalui observasi, angket, dokumentasi, wawancara dan pemberian tugas. Hasil penelitian menunjukkan bahwa pengembangan model pembelajaran dengan kemampuan generik ini mempunyai kelebihan: ketepatan waktu $76 \%$, kerja sama 92\%, Motivasi 94\%, tanggung jawab 74\% dan berpikir kritis 64\%. Adapun hasil kemampuan menulis cerpennya $94 \%$ kategori tinggi. Penelitian ini dapat disimpulkan bahwa pembelajaran dengan menggunakan pengembangan model pembelajaran kemampuan generik lebih baik dan dapat meningkatkan kualitas pembelajaran dan produk siswa.

Kata kunci: Pengembangan Model Pembelajaran, Kemampuan Generik, Menulis Cerpen.

\section{Pendahuluan}

Berdasarkan observasi dan keterangan yang telah peneliti lakukan terhadap beberapa orang siswa dan guru Bahasa dan Sastra Indonesia di sekolah menengah, pembelajaran menulis cerpen siswa masih tergolong belum berhasil dalam proses pembelajaran menulis cerpen, disebabkan oleh beberapa masalah. Pertama dalam pembelajaran menulis cerpen siswa 
kurang termotivasi untuk menulis. Siswa cenderung menjadi malas mengikuti pembelajaran menulis, bahkan hal itu mengakibatkan siswa menjadi malas mengikuti pembelajaran bahasa Indonesia secara keseluruhan. Oleh karena itu perlu adanya antisipasi secepatnya untuk permasalahan-permasalahan siswa dalam pembelajaran tersebut. Dengan didukung oleh antisipasi terhadap masalah motivasi siswa diharapkan pembelajaran akan berjalan dengan lancar dan siswa merasa senang mengikutinya. Beberapa siswa merasa tidak tahu bahwa menulis cerpen ada manfaatnya. Mereka mengaku bahwa guru bahasa Indonesia jarang memberitahukan manfaat menulis cerpen kepada siswanya. Agus Nuryatin (2008:12) menyatakan bahwa menulis cerpen memiliki beberapa manfaat, antara lain: cerpen dapat dijadikan sarana sebagai ekspresi pengalaman, perasaan, pemikiran, pendapat, dan gagasan, serta keterampilan menulis cerpen dapat dijadikan sebagai salah satu bentuk mata pencaharian. Kurangnya pengetahuan tentang manfaat menulis cerpen tersebut mengakibatkan rendahnya motivasi mereka dalam menulis cerpen.

Kedua, permasalahan proses pembelajaran. Siswa merasa kesulitan menemukan ide-ide cerita yang akan ditulis, ketidaksesuaian antara judul dengan isi cerpen, kurangnya kualitas ejaan dan tanda baca, kurangnya pendeskripsian pada tokoh, dan judul cerpen yang tidak mencerminkan isi cerita. Meskipun siswa telah diberikan pengetahuan tentang hal itu oleh guru berkali-kali, tetapi pada kenyataannya siswa masih belum bisa menerapkannya pada hasil cerpen mereka masing-masing.

Salah satu cara untuk mengatasi permasalahan pembelajaran menulis cerpen dengan model pembelajaran yang baru yaitu kemampuan generik sehingga dapat menjadi alternatif untuk meningkatkan kemampuan menulis cerpen siswa.
Penelitian dengan kemampuan generik ini baru pada bidang Sains. Pada hakekatnya kemampuan generik bisa diterapkan dalam berbagai disiplin ilmu. Hal ini sejalan dengan hasil kesimpulan dari sebuah proyek penelitian yang mengungkapkan keberadaan kemampuan generik (Chris Reynolds, 1997:115) yang menyatakan: the Key Competencies have the potential to benefit all students because they assist educators in realising the relevance of general education. Kemampuankemampuan kunci (kemampuan generik) mempunyai potensi untuk kepentingan semua siswa karena kemampuankemampuan tersebut membantu peserta didik dalam kaitannya dengan seluruh bidang pendidikan. Hal itulah yang mendasari bahwa kemampuan generik tidak hanya dapat diaplikasikan dalam bidang sains saja, tetapi bisa juga diterapkan dalam bidang bahasa.

Dengan melihat adanya penelitian berbasis kemampuan generik pada bidang sains dan pernyataan dalam penelitian oleh Chris Reynolds tersebut di atas serta kondisi-kondisi di lapangan tentang cerpen dan pembelajarannya, penelitian ini diarahkan untuk memodifikasi sebuah model pembelajaran berbasis kemampuan generik dalam pembelajaran menulis cerpen. Model ini diharapkan dapat meningkatkan kemampuan menulis cerpen siswa sehingga mampu menjadi sarana pembelajaran menulis cerpen yang berkualitas.

Penelitian ini dilakukan untuk mengetahui kondisi pembelajaran menulis cerpen di MAN 1 Mataram, pengembangan model pembelajaran kemampuan generik dalam menulis cerpen serta peningkatan kemampuan menulis cerpen siswa dengan model pembelajaran kemampuan generik.

\section{Kerangka Teori}

Aktivitas menulis merupakan salah satu keterampilan berbahasa paling akhir yang 
dikuasai pembelajar bahasa setelah mendengarkan, membaca, dan berbicara (Nurgiyantoro, 2001: 296).

Menurut Carino (1991) proses menulis berisi hal-hal sebagai berikut: invention (prewriting), penyusunan draf, revisi, dan penyuntingan (editing).

Berdasarkan keempat hal tersebut, maka dapat diketahui bahwa menulis tidak selalu berorientasi pada produk, tetapi juga memperhatikan proses menulis.

Cerpen merupakan cerita rekaan berbentuk prosa yang lebih mengarah pada kisahan yang pendek serta bersifat fiktif.. Pada pelaksanaan pembelajaranya siswa tidak hanya dituntut untuk mampu mengapresiasi tetapi juga menulis cerpen.

Model pembelajaran dapat didefinisikan sebagai suatu rencana mengajar yang memperlihatkan pola pembelajaran tertentu. Dalam pola pembelajaran tersebut terdapat karakteristik berupa tahapan kegiatan guru dan siswa, setiap tahapan merujuk pada rasional dan teori belajar sehingga model pembelajaran terlihat sebagai suatu desain yang menggambarkan proses rincian dan penciptaan situasi lingkungan kegiatan belajar mengajar.

Kemampuan generik telah berkembang luas di Amerika, Australia dan Eropa. Kemampuan generik pada awalnya merupakan istilah yang populer di dunia kerja namun seiring berjalannya waktu istilah ini berkembang dan menjadi bagian tak terpisahkan dengan sistem pendidikan, meskipun istilah yang digunakan berbedabeda. Beberapa istilah yang digunakan diantaranya adalah generic skills/key compentencies/employability skills (Australia), core skills/key skills/common skills (Inggris), key qualifications (Jerman), transferable skills (Perancis), employability skills (Kanada) dan basic skills/necessary skills (United States), (The Scottish Qualifications Authority, 2003: 6).
Di Indonesia, publikasi tentang kemampuan generik baru muncul pada tahun 2000-an, diantaranya melalui terbitnya Keputusan Menteri Tenaga Kerja dan Transmigrasi (Menakertrans) tahun 2003 tentang Tata Cara Penetapan Standar Kompetensi Kerja Nasional Indonesia (SKKNI).Lampiran keputusan menteri tentang SKKNI tersebut menyebutkan bahwa ada ada tujuh kompetensi kunci (key competencies) atau Kemampuan generik (generic skills) yang dibutuhkan untuk menyelesaikan suatu tugas atau pekerjaan. Ke-tujuh kompetensi kunci tersebut adalah: mengumpulkan, mengorganisir, dan menganalisis informasi; mengomunikasikan ide-ide dan informasi; merencanakan pengorganisasian aktivitas-aktivitas; bekerjasama dengan orang lain dan kelompok; menggunakan ide-ide dan teknik matematika; memecahkan masalah; dan menggunakan teknologi (Menakertrans, 2009:29).

Di berbagai negara dirumuskan kemampuan generik yang bisa diterapkan dalam berbagai bidang disiplin ilmu. Misalnya di Australia kemampuan generik dirumuskan berdasarkan rumusan yang diciptakan oleh Eric Mayer. Ada tujuh kemampuan kunci yang dipresentasikan oleh Mayer pada tahun 1992: This report identified seven key competencies which people should acquire before they moved into the workforce. These are:

1. Collecting, analysing and organising information

2. Communicating ideas and information

3. Planning and organising activities

4. Working with others in teams

5. Solving problems

6. Using mathematical ideas and techniques

7. Using technology (The Scottish Qualifications Authority,2003: 6) 
Dengan melihat tujuh kemampuan kunci Mayer yang dikenal dengan The Key Competencies Report tersebut dapat ditemukan bahwa kemampuan generik yang ada di Indonesia diadaptasi darinya.Kemampuan-kemampuan kunci ini dapat diaplikasikan dalam berbagai disiplin ilmu.Karena itulah kemampuan ini dapat dijadikan pondasi memodifikasi sebuah model pembelajaran.

Jika kemampuan generik dapat dijadikan sebagai dasar memodifikasi sebuah model pembelajaran, maka dibutuhkan indikator pembelajaran berdasarkan kemampuan generik tersebut. Indikator kemampuan generik dapat dilihat melalui cakupan kemampuan yang ada di dalamnya sesuai dengan table di bawah ini.

Tabel 1. Pembelajaran Berbasis

Kemampuan Generik

\begin{tabular}{|c|c|c|}
\hline $\begin{array}{l}\text { KEMAMP } \\
\text { UAN } \\
\text { GENERIK }\end{array}$ & $\begin{array}{l}\text { PENGER } \\
\text { TIAN }\end{array}$ & $\begin{array}{l}\text { CAKUPAN } \\
\text { KEMAMPU } \\
\text { AN }\end{array}$ \\
\hline $\begin{array}{l}\text { Mengumpu } \\
\text { lkan, } \\
\text { menganalis } \\
\text { is dan } \\
\text { mengorgani } \\
\text { sasikan } \\
\text { informasi. }\end{array}$ & $\begin{array}{l}\text { Kemampua } \\
\mathrm{n} \text { untuk } \\
\text { menemuka } \\
\mathrm{n} \text {, } \\
\text { menyaring } \\
\text { dan } \\
\text { memilah } \\
\text { informasi } \\
\text { untuk } \\
\text { memilih } \\
\text { apa yang } \\
\text { diperlukan } \\
\text { dan } \\
\text { menyajikan } \\
\text { nya dengan } \\
\text { cara yang } \\
\text { bermanfaat. }\end{array}$ & $\begin{array}{l}\text { Mencari } \\
\text { informasi } \\
\text { dalam erbagai } \\
\text { sumber.Menya } \\
\text { ring dan } \\
\text { emilah-milah } \\
\text { data.Mencatat } \\
\text { efektif. } \\
\text { Mengkategori } \\
\text { kan dan } \\
\text { menghubungk } \\
\text { an informasi. }\end{array}$ \\
\hline $\begin{array}{l}\text { Mengkomu } \\
\text { nikasikan } \\
\text { ide dan } \\
\text { informasi }\end{array}$ & $\begin{array}{l}\text { Kemampua } \\
\text { n untuk } \\
\text { berkomuni } \\
\text { kasi secara } \\
\text { efektif } \\
\text { dengan }\end{array}$ & $\begin{array}{l}\text { Menggunakan } \\
\text { teknik bahasa } \\
\text { lisan untuk } \\
\text { berkomunikasi } \\
\text { secara efektif } \\
\text { dengan orang }\end{array}$ \\
\hline
\end{tabular}

\begin{tabular}{|c|c|c|}
\hline & $\begin{array}{l}\text { orang lain } \\
\text { menggunak } \\
\text { an berbagai } \\
\text { diucapkan, } \\
\text { berarti non- } \\
\text { verbal } \\
\text { tertulis, } \\
\text { grafis dan } \\
\text { lain } \\
\text { berekspresi. }\end{array}$ & $\begin{array}{l}\text { lain. } \\
\text { Menggunakan } \\
\text { teknik bahasa } \\
\text { tulis untuk } \\
\text { berkomunikasi } \\
\text { secara efektif } \\
\text { dengan orang } \\
\text { lain secara } \\
\text { tertulis. } \\
\text { Menggunakan } \\
\text { teknik grafis } \\
\text { untuk } \\
\text { berkomunikasi } \\
\text { secara efektif } \\
\text { dengan orang } \\
\text { lain. } \\
\text { Menggunakan } \\
\text { sarana ekspresi } \\
\text { non-verbal } \\
\text { lainnya untuk } \\
\text { berkomunikasi } \\
\text { secara efektif } \\
\text { dengan orang } \\
\text { lain. }\end{array}$ \\
\hline $\begin{array}{l}\text { Merencana } \\
\text { kan dan } \\
\text { mengorgani } \\
\text { sir kegiatan }\end{array}$ & $\begin{array}{l}\text { Kemampua } \\
\text { n untuk } \\
\text { merencana } \\
\text { kan dan } \\
\text { mengatur } \\
\text { kerja } \\
\text { sendiri, } \\
\text { termasuk } \\
\text { mengefekti } \\
\text { fkan } \\
\text { penggunaa } \\
\text { n waktu } \\
\text { dan sumber } \\
\text { daya, dan } \\
\text { pemantaua } \\
\text { n kinerja } \\
\text { sendiri. }\end{array}$ & $\begin{array}{l}\text { Perencanaan } \\
\text { dan } \\
\text { pengorganisasi } \\
\text { an pekerjaan } \\
\text { sendiri. } \\
\text { Efektifitas } \\
\text { penggunaan } \\
\text { waktu. } \\
\text { Memanfaatkan } \\
\text { sumber daya } \\
\text { yang baik. } \\
\text { Pemantauan } \\
\text { kinerja } \\
\text { sendiri. }\end{array}$ \\
\hline $\begin{array}{l}\text { Bekerja } \\
\text { dengan } \\
\text { orang lain } \\
\text { dan dalam }\end{array}$ & $\begin{array}{l}\text { Kemampua } \\
\mathrm{n} \text { untuk } \\
\text { berinteraksi } \\
\text { secara }\end{array}$ & $\begin{array}{l}\text { Berinteraksi } \\
\text { secara efektif } \\
\text { dengan orang } \\
\text { lain. }\end{array}$ \\
\hline
\end{tabular}




\begin{tabular}{|c|c|c|}
\hline tim & $\begin{array}{l}\text { efektif } \\
\text { dengan } \\
\text { orang lain } \\
\text { baik secara } \\
\text { satu-ke- } \\
\text { satu dan } \\
\text { dalam } \\
\text { kelompok- } \\
\text { kelompok, } \\
\text { termasuk } \\
\text { bekerja } \\
\text { secara } \\
\text { efektif } \\
\text { sebagai } \\
\text { anggota tim } \\
\text { untuk } \\
\text { mencapai } \\
\text { tujuan } \\
\text { bersama. }\end{array}$ & $\begin{array}{l}\text { Bekerja secara } \\
\text { efektif sebagai } \\
\text { anggota tim } \\
\text { untuk } \\
\text { mencapai } \\
\text { tujuan } \\
\text { bersama. }\end{array}$ \\
\hline $\begin{array}{l}\text { Menggunak } \\
\text { an gagasan } \\
\text { matematis } \\
\text { dan teknik }\end{array}$ & $\begin{array}{l}\text { Kemampua } \\
\text { n untuk } \\
\text { menggunak } \\
\text { an ide-ide } \\
\text { matematika } \\
\text {, seperti } \\
\text { jumlah dan } \\
\text { ruang, dan } \\
\text { teknik, } \\
\text { seperti } \\
\text { estimasi } \\
\text { dan } \\
\text { aproksimas } \\
\text { i, untuk } \\
\text { tujuan } \\
\text { praktis; } \\
\text { juga } \\
\text { melibatkan } \\
\text { kemampua } \\
\text { n untuk } \\
\text { berurusan } \\
\text { dengan } \\
\text { uang, } \\
\text { misalnya } \\
\text { penerimaan } \\
\text { perubahan, }\end{array}$ & $\begin{array}{l}\text { Menggunakan } \\
\text { gagasan } \\
\text { matematis, } \\
\text { seperti jumlah } \\
\text { dan ruang, } \\
\text { untuk tujuan } \\
\text { praktis. } \\
\text { Menggunakan } \\
\text { teknik } \\
\text { matematika, } \\
\text { seperti } \\
\text { estimasi untuk } \\
\text { tujuan praktis. } \\
\text { Berurusan } \\
\text { dengan } \\
\text { masalah uang } \\
\text { dan keuangan, } \\
\text { misalnya } \\
\text { penerimaan, } \\
\text { perubahan, dll. }\end{array}$ \\
\hline
\end{tabular}

\begin{tabular}{|c|c|c|}
\hline & dll. & \\
\hline $\begin{array}{l}\text { Memecahk } \\
\text { an Masalah }\end{array}$ & $\begin{array}{l}\text { Kemampua } \\
\text { n untuk } \\
\text { mencari } \\
\text { solusi } \\
\text { dalam } \\
\text { situasi di } \\
\text { mana } \\
\text { masalah } \\
\text { dan solusi } \\
\text { yang } \\
\text { diinginkan } \\
\text { yang jelas } \\
\text { serta dalam } \\
\text { situasi yang } \\
\text { membutuhk } \\
\text { an } \\
\text { pemikiran } \\
\text { kritis dan } \\
\text { pendekatan } \\
\text { kreatif. }\end{array}$ & $\begin{array}{l}\text { Mendefinisika } \\
\text { n dan } \\
\text { mamahami } \\
\text { sebuah } \\
\text { masalah. } \\
\text { Menghasilkan } \\
\text { ide yang } \\
\text { banyak, } \\
\text { bervariasi. } \\
\text { Merumuskan } \\
\text { rencana yang } \\
\text { spesifik untuk } \\
\text { dilaksanakan. }\end{array}$ \\
\hline $\begin{array}{l}\text { Menggunak } \\
\text { an } \\
\text { Teknologi }\end{array}$ & $\begin{array}{l}\text { Kemampua } \\
\text { n untuk } \\
\text { menggunak } \\
\text { an } \\
\text { teknologi, } \\
\text { termasuk } \\
\text { kemampua } \\
\text { n untuk } \\
\text { mengopera } \\
\text { sikan, } \\
\text { mengatur } \\
\text { dan uji } \\
\text { peralatan, } \\
\text { mengikuti } \\
\text { instruksi } \\
\text { atau } \\
\text { bekerja } \\
\text { secara } \\
\text { independen } \\
\text {. }\end{array}$ & $\begin{array}{l}\text { Menggunakan } \\
\text { internet } \\
\text { (termasuk } \\
\text { mesin pencari } \\
\text { dan } \\
\text { yellowpages.c } \\
\text { om) untuk } \\
\text { mencari } \\
\text { informasi. } \\
\text { Menggunakan } \\
\text { PowerPoint } \\
\text { untuk } \\
\text { mengkomunik } \\
\text { asikan gagasan } \\
\text { secara jelas } \\
\text { dan efektif. } \\
\text { Menggunakan } \\
\text { excel untuk } \\
\text { membuat } \\
\text { worksheet dan } \\
\text { grafik. } \\
\text { Set up, } \\
\text { pengoperasian, }\end{array}$ \\
\hline
\end{tabular}




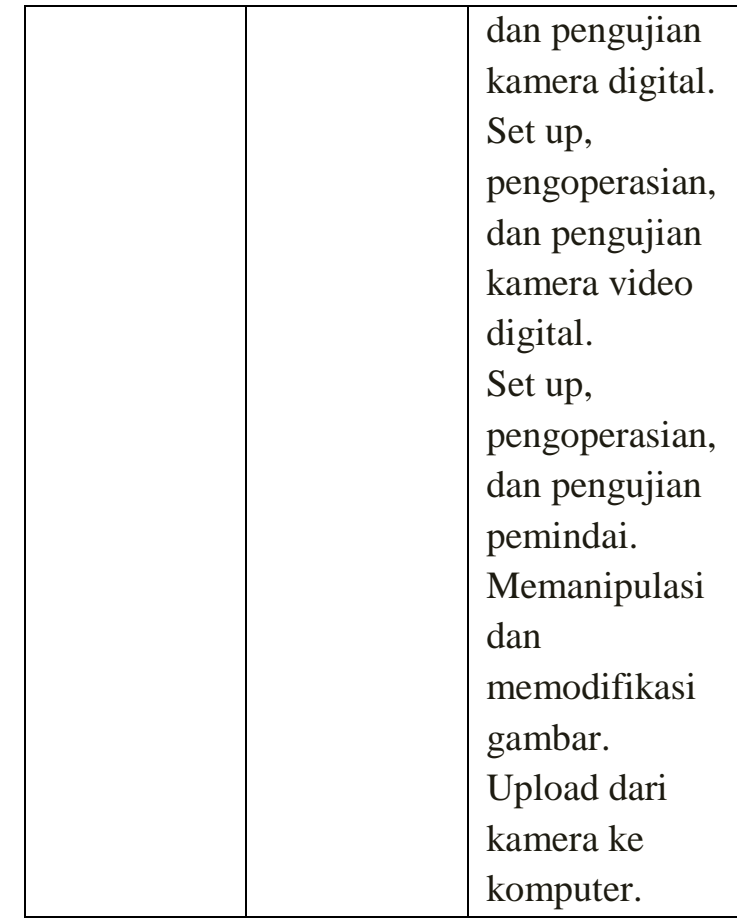

Teori lain yang mendukung penelitian ini adalah strukturalisme genetik oleh Lucien Goldmann. Menurut Faruk (2003:12) Goldmann percaya bahwa karya sastra merupakan sebuah struktur. Artinya, ia tidak berdiri sendiri, melainkan banyak hal yang menyokongnya sehingga ia menjadi satu bangunan yang otonom. Teori ini akan digunakan untuk menganalisis hubungan antara hasil karya siswa dengan unsur yang ada di luar sastra dan mempengaruhi proses penciptaan karya sastra khususnya cerita pendek. Karya siswa karena berlatar belakang anak SMA/MA, maka yang menjadi tema karyanya adalah sekitar percintaan di sekolah, kesederhanaan karena berlatar belakang keluarga yang sederhana, kasih sayang orang tua dan persahabatan. Penelitian ini dibatasi faktor yang dimaksudkan di atas tanpa menganalisis data dengan mendalam terkait dengan teori struktural genetik ini.

\section{Metode Penelitian}

Pendekatan yang digunakan dalam penelitian ini adalah pendekatan yang mempadukan kualitatif dan kuantitatif, sedangkan sifat penelitian adalah Etnografi
Kelas (Clasroom Etnography). Etnografi (observasi partisipasi) kelas merupakan penelitian yang mendeskripsikan sebuah budaya sekolah dalam komunitas kelas yang sedang diteliti atau dipelajari sehingga data yang diperoleh dalam penelitian ini melalui pengamatan terhadap objek penelitian yaitu budaya belajar menulis cerpen siswa MAN 1 Mataram. (Hadi, Sutrinso. 2000)

Peneliti berperan sebagai pengamat. Penelitian dilaksanakan di MAN 1 Mataram pada Kelas XI IPA 2 jumlah siswa 39 yang terdiri dari 7 orang siswa laki-laki dan 32 orang siswa perempuan.

Populasi adalah seluruh individu yang menjadi subjek penelitian dan akan digeneralisasikan (Arikunto, 2002:109). Penentuan jumlah sampel tergantung pada besarnya jumlah populasi, "jika populasi kurang dari 100, dianjurkan agar semuanya dijadikan sampel. Namun jika populasi lebih dari 100, maka dapat diambil 10-15\%, 20$25 \%$ atau lebih tergantung kemampuan peneliti". (Arikunto, 2006:134).

Sampel adalah bagian dari jumlah dan karakteristik yang dimiliki oleh populasi (Sugiono, 2008:62).

Penelitian ini sebenarnya terdiri dari tiga kelas perwakilan yaitu kelas X, XI, dan XII, tetapi karena masing-masing mempunyai alasan tertentu maka hanya satu kelas yang digunakan yaitu kelas XI IPA 2. Adapun alasan tidak mengambil kelas $\mathrm{X}$ disebabakan pemahaman siswa kelas $\mathrm{X}$ masih kurang kritis terhadap penulisan cerpen karena masa transisi dari MTs ataupun SMP, kemudian alasan tidak mengambil Kelas XII disebabkan bahwa kelas XII berbenturan dengan Ujian Akhir Nasional. Oleh karena itu maka diambillah kelas XI IPA 2.Dalam komunitas kelas XI IPA 2 terdapat siswa yang heterogen, mulia dari yang memiliki kemampuan rendah, sedang maupun tinggi. Jenis sampel yang digunakan adalah Sampel Nonprobabilitas dengan kategori sampel purposif. Adapun 
pengumpulan data dilakukan melalui observasi/pengamatan, angket, dokumentasi, dan wawancara/interview dan pemberian tugas. Data yang diperoleh dianalisis secara deskriptif kualitatif dengan menggambarkan apa adanya yang terjadi dalam proses pembelajaran khususnya menulis cerpen dengan pengembangan model kemampuan generik. Tingkat kemampuan menulis cerpen didasarkan pada kriteria penilaian acuan patokan (PAP). Adapun pedoman konversinya adalah seperti pada tabel 2 .

$$
\text { Tabel }
$$

Tabel 2. Konversi skor penilaian menulis cerpen dengan pengembangan kemampuan generik menjadi kategori kemampuan (Arikunto, 2002)

\begin{tabular}{|c|c|}
\hline Skor Nilai & $\begin{array}{c}\text { Kategori } \\
\text { Kemampuan }\end{array}$ \\
\hline $85-100$ & Baik sekali \\
$70-84$ & Baik \\
$55-69$ & Cukup \\
$40-54$ & Kurang \\
$0-39$ & Kurang sekali \\
\hline
\end{tabular}

Selama ini pembelajaran yang terjadi dengan model konvensional dapat dilihat dari hasil produk siswa yaitu cerpen tidak maksimal, masih banyak terjadi kesalahan. Peningkatan kemampuan menulis cerpen dapat diperoleh dengan model pengembangan kemampuan generik.

Secara garis besar alur yang digunakan dalam penelitian ini dapat dilihat dalam gambar. Pembelajaran menulis cerpen dengan pengembangan kemampuan generik melibatkan serangkaian kegiatan yang terencana dan bertahap. Pada bagian akhir penelitian ini dilakukan analisis terhadap peningkatan kemampuan menulis cerpen dan respon siswa terhadap pengembangan model generik.

\section{ALUR MODEL PEMBELAJARAN BERBASIS KEMAMPUAN GENERIK}

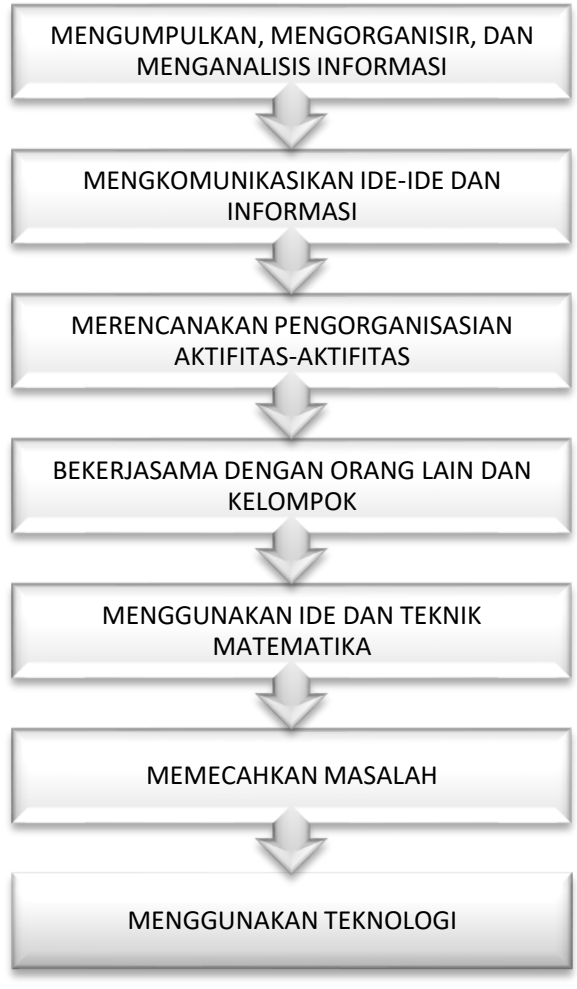

Dalam rangka peningkatan kemampuan menulis cerpen berbagai upaya dilakukan oleh guru Bahasa dan Sastra Indonesia. Untuk mendukung upaya yang dilakukan oleh guru ditemukan alternatif model pembelajaran berbasis kemampuan generik. Model pembelajaran ini menawarkan pembelajaran yang menekankan pada kolaborasi antara kemampuan generik dengan keterampilan proses menulis. Dengan adanya model ini diharapkan siswa melalui tahapan-tahapan yang optimal dalam proses menulis cerpen. Dengan demikian akan tercipta cerpencerpen yang berkualitas beredar di masyarakat.

Pengembangan model pembelajaran menulis cerpen berbasis kemampuan generik adalah:

1. Mengumpulkan, mengorganisir, dan menganalisis informasi 
Guru membangun pengetahuan siswa tentang menulis cerpen, guru menjelaskan manfaat kita menulis cerpen. Guru menyuruh siswa menyaring, memilah, mengorganisir, dan menganalisis informasi dari berbagai sumber. Hal itulah yang dijadikan sebagai ide cerita dalam menulis.

2. Mengkomunikasikan ide-ide dan informasi yang didapat dengan teman sebangku atau teman sekelas lainnya. Guru memberikan pemodelan yaitu suatu cerita dijadikan contoh, mana yang temasuk penggalan perkenalan (oreantasi), pertikaian, konflik mulai terjadi (komplikasi), konflik berkembang semakin rumit, klimaks, dan peleraian/solusi penyelesaian. Dalam penulisan cerpen wajib mengikuti pola alur tersebut.

3. Merencanakan pengorganisasian aktivitas-aktivitas

Dari pemodelan yang diberikan tersebut, maka siswa dibuat berkelompok, dari 39 siswa ditentukan dan menjadi 5 kelompok, jadi masingmasing kelompok dibagi menjadi 8 dan 7 orang siswa. Masing-masing kelompok atau individu mulai membuat kerangka cerita pendek, merencanakan dan mengatur kerja sendiri, termasuk mengefektifkan penggunaan waktu dan sumber daya, dan pemantauan kinerja sendiri dan mulai menulis cerita pendek, yang ditulis adalah bagianbagian dari pola alur, ada yang menulis pola pengenalan, konflik, klimaks dan lainnya.

4. Bekerja sama dengan orang lain dan kelompok. Dalam bagian ini, cerpen yang ditulis didiskusikan dengan teman atau kelompok dan guru mengarahkan.

5. Menggunakan ide dan teknik matematika yaitu mulai menulis cerpen yang utuh (konstruksi wacana mandiri, dikerjakan dalam bentuk tugas di rumah) dan menyelarasakan keseimbangan unsur-unsur yang ada dalam cerpen seperti penokohan, alur, latar dan lain-lain.

6. Memecahkan masalah yaitu menemukan kekurangan dan mengedit cerpen yang ditulis.

7. Menggunakan teknologi, dengan teknologi hasil karya yang berupa cerpen tersebut dipublikasikan.

\section{Pembahasan}

\subsection{Kondisi Pembelajaran}

Berdasarkan data, siswa banyak yang tidak mau mengkomunikasikan idenya pada teman sebangku dan kelompok, setelah ditanya hal ini disebabkan karena siswa: a) malu dan takut menyampaikan idenya, ini adalah faktor mental), b) tidak mau pengalaman yang ditulis diketahui oleh orang lain, c) adanya suara hati negatif yang selalu meremahkan usaha siswa. Ini merupakan faktor siswa tidak mau mengkomunikasikan idenya dengan temannya. Untuk melenyapkan suara hati yang senang menghina, dorongan dan penegasan dari guru dan teman sangat membantu dan meyakinkan siswa bahwa mereka berharga dan mampu melakukan di atas kemampuannya. Penegasan (afirmasi) juga membantu siswa mengembangkan harga diri. Penegasan adalah sebuah pernyataan tertulis yang singkat, jelas, sederhana dan positif dari siswa yang dinyatakan dalam bentuk sekarang (Cameron, 1992) misalnya penegasan saya seorang yang imajinatif, saya berpikiran terbuka dan mau menerima ide-ide baru. Itu merupakan contoh-contoh penegasan yang dilakukan oleh siswa. Tidak disangka bahwa dengan adanya penegasan maka siswa semakin bertambah kreatif dan anehnya hal tersebut mempunyai kekuatan yang mendorong seorang siswa untuk berkreativitas. Setelah siswa mendapatkan 
ide dan merumuskan masalahnya, maka guru menyuruh siswa segera memikirkan logika cerita dan jawaban sebelum dituliskan. Logika dan jawaban ini bisa diperoleh dengan pengetahuan dan imajinasi, tetapi jika logika ini bisa dibangun dengan dasar agama, budaya dan ilmu pengetahuan, hal ini bisa memperlihatkan kualitas cerpen yang ditulis. Adapun Teknik yang digunakan adalah diskusi yaitu mendiskusikan dengan teman yang lain. Teknik inilah yang digunakan oleh siswa dan termasuk tahap dalam model kemampuan generik.

4.2. Peningkatan kemampuan menulis cerpen siswa dengan model pembelajaran berbasis kemampuan generik

Pengembangan model kemampuan generik pada pembelajaran menulis cerpen akan lebih bermakna dan berkualitas hasil produk cerpennya atau hasil belajar siswa bila disesuaikan dengan situasi dan kondisi yang menunjang. Pengembangan model tersebut dilaksanakan penuh dengan kesungguhan dan ketulusan hati, tanpa rasa terpaksa dan dipaksa oleh siapapun serta sesuai dengan hakekat ilmu yang diajarkan kepada siswa. Uji coba terbatas yang dilakukan pada kelas XI IPA 2 Madrasah Aliyah Negeri 1 Mataram menunjukkan hasil yang cukup signifikan. Hal ini terbukti dengan meningkatnya hasil belajar siswa dari sebelum dan setelah dilaksanakan pembelajaran berbasis kemampuan generik.

\subsection{Pengembangan model}

a. Mengumpulkan, mengorganisir, dan menganalisis informasi.

Dalam menulis cerpen diperlukan ide. Ide adalah masalah yang bersumber dari peristiwa ataupun benda. Permasalahan yang terjadi ketika pembelajaran berlangsung, tahap pertama dalam kemampuan generik ini berdasarkan data, siswa mengajukan pernyataan pada guru bahwa waktu yang diberikan untuk mengumpulkan informasi dalam hal mencari ide adalah kurang, hal ini disebabkan oleh siswa kurang membaca dan tidak peka terhadap objek alam di sekitarnya. Jika manusia mau mencarai ide, ide tidak berada jauh, ide berteberangan di mana-mana. Itu orang yang cepat mendapatkan ide tetapi berbeda ketika orang lain susah mendapatkan ide karena ada ide yang datang tetapi ide karena pada saat ide itu datang, ide tersebut diabaikan, hal inilah yang bisa menjadikan ide itu susah ada.

Logika dalam menulis cerpen sama dengan menulis karya ilmiah. Bedanya, masalah dalam cerpen dipecahkan dengan logika, fantasi dan imajinasi, sedangkan karya ilmiah dengan logika karya ilmiah. Implikasinya, menulis cerpen bersifat subjektif, sedangkan karya ilmiah bersifat objektif. Subjektivitas inilah yang membuat siswa dalam membuat cerpen mempunyai ruang yang luas untuk mengembangkan imajinasi dan fantasi dalam memecahkan persoalan sebagai sumber ide cerpen. Masalah yang sekaligus sebagai sumber ide dalam ide menulis cerpen adalah ketertarikan siswa pada fenomena atau benda yang membangkitkan rasa ingin menulis cerpen. Hidup merupakan rangkaian peristiwa dalam gerak ruang yang berpindah-pindah.Dalam peristiwa dan ruang itulah siswa selalu mendapatkan halhal yang menarik bagi dirinya sendiri. Hal yang menarik itulah yang disebut dengan permasalahan sebagai sumber ide menulis cerpen. Banyak objek dan sumber inspirasi untuk dijadikan sebagai ide, antara lain majalah, menonton tv, berita, foto-foto ataupun kejadian yang berdasarkan pada pengalaman.

b. Mengkomunikasikan ide dan informasi yang didapat dengan kelompok.

Berdasarkan data, siswa banyak yang tidak mau mengkomunikasikan idenya pada teman sebangku dan kelompok, setelah ditanya hal ini disebabkan karena siswa: a) 
malu dan takut menyampaikan idenya, ini adalah faktor mental), b) tidak mau pengalaman yang ditulis diketahui oleh orang lain, c) adanya suara hati negatif yang selalu meremahkan usaha siswa.Ini merupakan faktor siswa tidak mau mengkomunikasikan idenya dengan temannya. Untuk melenyapkan suara hati yang senang menghina, dorongan dan penegasan dari guru dan teman sangat membantu dan meyakinkan siswa bahwa mereka berharga dan mampu melakukan di atas kemampuannya. Penegasan (afirmasi) juga membantu siswa mengembangkan harga diri. Setelah siswa mendapatkan ide dan merumuskan masalahnya, maka guru menyuruh siswa segera memikirkan logika cerita dan jawaban sebelum dituliskan. Logika dan jawaban ini bisa diperoleh dengan pengetahuan dan imajinasi, tetapi jika logika ini bisa dibangun dengan dasar agama, budaya dan ilmu pengetahuan, maka hal ini bisa memperlihatkan kualitas cerpen yang ditulis. Adapun Teknik yang digunakan adalah diskusi yaitu mendiskusikan dengan teman yang lain.

$$
\begin{aligned}
& \text { c. Tahap kontemplasi atau } \\
& \text { pengendapan } \\
& \text { Pada tahap ini dilakukan bersamaan }
\end{aligned}
$$
saat itu juga, yaitu sesudah mendapatkan ide. Dengan melihat fakta bahwa satu ide bisa dirumuskan menjadi beberapa permasalahan, dan setiap permasalahan dalam proses pengendapannya mempunyai logika jawaban dan ceritanya sendiri-sendiri, maka satu ide, baik benda ataupun peristiwa bisa dijadikan beberapa cerpen. (tahap ini dalam kemampuan generik dikenal dengan menggunakan ide dan teknik matematika)

Untuk mendapatkan ide kemudian menghasilkan logika jawaban dari rangkaian peristiwa, yang perlu diperhatikan oleh siswa adalah kehadiran konflik dan keterkejutan dalam cerpen. Hal ini agar pembaca menikmati cerpen tidak hanya ingin menikmati peristiwanya, tetapi ingin juga mendapatkan ketegangan dan keterkejutan yang membuatnya berpikir karena tidak menduga tentang hal yang akan terjadi dalam cerpen. Inilah kemenarikan dari cerpen, konflik dan penyelesaiannya, idealnya mengejutkan sesuai dengan daya fantasi dan imajinasi penulisnya.

Dalam tahap ini bekerja sama dikaitkan dengan pendekatan CTL (Contextual Teaching Learning) bekerjasama merupakan komponen penting dalam CTL. Para pengkritik pola kerjasama percaya bahwa jika siswa bekerja dalam sebuah kelompok kecil, mereka tanpa kecuali akan saling mengabaikan, menerima beban tugas yang tidak sama, berperilaku tidak efisien, dan saling berdebat. Hal ini merupakan kelemahan yang terjadi pada penerapan MKG 1. Sementara itu, penganjur pola bekerja sama yakin bahwa berbagai masalah tersebut dapat dihindari dengan mudah dan menunjukkan banyak keuntungan yang diperoleh dari bekerja sama dalam kelompok kecil. Kerja sama dapat menghasilkan hambatan mental akibat terbatasnya pengalaman dan cara pandang yang sempit. Ini membuktikan bahwa siswa dapat menemukan kekuatan dan kelemahan diri, belajar untuk menghargai orang lain, mendengarkan dengan pikiran terbuka, dan membangun persetujuan bersama. Dengan bekerja sama para anggota kelompok kecil akan mampu mengatasi berbagai rintangan, bertindak mandiri dan dengan penuh tanggung jawab, mengandalkan bakat setiap anggota kelompok, mempercayai orang lain, mengeluarkan pendapat, dan mengambil keputusan. Kegiatan ini dimaksimalkan dalam MKG 2. Di samping model kemampuan generik yaitu tahap kerja sama dalam kelompok adalah suatu kelemahan tetapi jika dimaksimalkan dan adanya kesadaran diri dari masing-masing anggota kelompok, maka kegiatan itu menjadi sebuah kelebihan. 
d. Penulisan cerpen yang utuh (konstruksi wacana mandiri, dikerjakan dalam bentuk tugas di rumah)

Berdasarkan data, proses penulisan ini adalah tahap yang paling sulit dilakukan oleh siswa dalam proses menulis cerpen, karena berbagai kendala selalu ada, terutama bagi siswa pemula, malas dan susah merupakan masalah dasar. Keterampilan menulis merupakan keterampilan yang paling sukar dan rumit di antara jenis-jenis keterampilan berbahasa lainnya antara lain mendengarkan (menyimak), berbicara dan membaca. Ini karena menulis bukanlah sekedar menyalin kata-kata dan kalimatkalimat, melainkan juga mengembangkan dan menuangkan pikiran-pikiran dalam suatu struktur tulisan yang teratur. Peran guru sangat penting di sini, guru meyakinkan pada diri siswa untuk menulis.Jangan berpikir yang pesimis tentang hasil yang tidak baik. Guru meyakinkan siswa bahwa apa yang ditulis itu bermanfaat bagi diri sendiri. Dalam menulis siswa mendapatkan ide, menulis dan merevisi atau membolak-balik sampai akhirnya tulisan selesai. Teruslah menulis tulisan setiap kali setelah melalui proses penemuan ide. Intensitas untuk terus menulis akan membuat siswa semakin ahli dan mahir dalam menulis cerpen. Guru memberikan penekanan bahwa menulis adalah keterampilan yang hanya bisa dikuasai dengan baik apabila berlatih terus setiap harinya.

Untuk mengevaluasi kesulitan siswa dalam menulis cerpen guru melakukan wawancara (interview). Wawancara ini dilakukan oleh guru kepada siswa untuk mendeteksi titik kelemahan yang dialami setiap siswa. Sebelum dan sesudah menyusun cerpen, guru berdiskusi dengan siswa tentang kendala yang dialami siswa. Akhirnya, dari situlah guru dapat menentukan langkah untuk memecahkan masalah yang dihadapi siswa dalam menulis cerpen.

Prinsip utama yang harus dijunjung tinggi dalam menuliskan ide adalah harus saat itu juga dan harus jadi. Jika ide yang diolah sudah matang, maka siswa segera manulis pada hari itu juga.Menulis itu adalah intensitas dan ketelatenan.Jika cerpen yang ditulis sudah jadi, maka satu momen estetik sudah siswa perlakukan dengan baik. Dan sudah mendokumentasikannya. Semua percaya, jika menulis cerpen terus dilakukan dengan intens, maka siswa akan terbentuk kepribadian penulis yang kuat, yaitu selalu merasa perlu dan butuh untuk selalu menuliskan setiap momen yang estetik. Hasilnya secara kualitas, siswa akan semakin punya skills dalam menulis, semakin peka terhadap fenomena yang bisa menjadi sumber ide, dan pasti tulisan siswa akan semakin berkualitas.

\section{e. Memecahkan masalah dengan menemukan kekurangan dan mengedit cerpen yang ditulis}

Berdasarkan data cerpen yang ditulis siswa mengakatakan bahwa cerpen yang telah dibuat sudah diedit oleh penulis (siswa) itu sendiri tetapi berdasarkan catatan yang dilakukan oleh peneliti menunjukkan bahwa siswa masih banyak penulisan yang salah padahal kata mereka (siswa) sudah diedit, hal ini terjadi karena siswa berasumsi bahwa tulisannya sudah benar dan menarik, akan tetapi ketika dibaca oleh orang lain ternyata masih ada yang salah. Oleh karenanya tahap ini sangat penting sekali untuk menghasilkan produk cerpen yang berkualitas.

Dari uraian di atas, disimpulkan bahwa cerpen yang sudah ditulis selesai, bukan berarti cerpen itu sudah jadi atau final. Cerpen yang ditulis itu pada tahap ini baru merupakan hasil impresi ide-ide yang diendapkan, belum sebagai hasil logika rasionalitas. 
Dalam implikasinya, pasti akan tejadi banyak kesalahan penulisan, alur yang tidak kronologis, anakronisme, dan konflik yang datar dan tidak dramatik. Untuk mengatasi persoalan ini, harus melakukan tahap selanjutnya yaitu editing atau revisi. Tahap editing berkaitan dengan pembetulan aspek kebahasaan dan penulisan sedangkan tahap revisi berkaitan dengan isi misalnya alur yang tidak kronologis, anakronisme, kesalahan bercerita, konflik yang datar dan tidak dramatik sehingga tahap editing dan revisi sangat diperlukan dalam membuat cerpen.

Dalam proses pembacaan inilah editing dan revisi sedang dilakukan. Guru menjelaskan bahwa siswa dalam tahap editing dan revisi ini dalam sekali duduk jadi karena jika ini dipotong ditengah jalan dan dilanjutkan lagi esoknya, maka proses editing dan revisi pun harus di mulai dari awal lagi. Hal ini dilakukan karena setiap kondisi rasa, akan menghasilkan cara dan persepsi yang berbeda dalam memandang cerpen yang sudah dicipta. Maka, sekali edit dan revisi haruslah langsung jadi.

Apabila cerpen yang ditulis sudah jadi, maka dicetak dan dibaca berulang kali. Hal ini harus dilakukan karena keakuratan pembacaan dalam komputer kurang maksimal. Maka perlu dilakukan pembacaan lewat hasil cetak. Namun demikian, jika tahap ini sudah selesai, ada tahap penting yang bisa dilakukan yaitu memberikan hasil cerpen pada siswa lain dan guru guna menyempurnakannya. Siswa meminta kepada temannya yang lain untuk membaca atau mengedit serta memberi komentar atas cerpen yang telah dibuat. Dengan cara ini, maka siswa bisa banyak belajar dan semakin teliti lagi dalam melakukan revisi atau editing kerena telah melibatkan persepsi orang lain.

Guru melakukan revisi dan evaluasi setiap cerpen siswa serta memberikan penguatan (reinforcement. Pemberian revisi dan evaluasi pada setiap cerpen siswa dan memberikan penguatan (reinforcement) sangatlah diperlukan.Setiap hasil cerpen siswa diberikan revisi dan evaluasi guna melihat tingkat kemampuan siswa sampai pada akhir mengumpulkan cerpen. Di samping itu, diberikan semacam penguatan atau penghargaan (reinforcement) kepada siswa. Selain guru menunjukkan letak kekurangan cerpen mereka juga menunjukkan kelebihan-kelebihan cerpen yang disusunnya. Setelah cerpen-cerpen tersebut direvisi dan dievaluasi, guru juga memberikan penghargaan kepada siswa yang cerpennya menduduki lima cerpen terbaik yang layak untuk ditampilkan dalam madding atau diusulkan untuk dimuat dalam media massa. Dengan langkah tersebut ternyata siswa semakin terpacu dalam berkarya untuk membuahkan hasil karya terbaiknya.

Menggunakan teknologi yaitu dengan media cetak atau on line hasil karya yang berupa cerpen tersebut dipublikasikan.

Berkaitan dengan hasil belajar siswa, model kemampuan generik banyak dikontribusi oleh suasana, situasi dan pola interaksi belajar yang terjadi dalam hubungan dengan penggunaan model pembelajaran tersebut. Kondisi ini tumbuh dan berkembang didukung oleh beberapa faktor yang berhubungan dengan proses pelaksanaan pembelajaran dalam menerapkan model pengembangan kemampuan generik. Faktor penampilan guru dalam melaksanakan pembelajaran di setiap pertemuan menunjukkan keaktifannya yang semakin meningkat dari setiap pertemuan sehingga siswa pun ikut termotivasi dengan semangat guru yang semakin meningkat. Faktor inilah yang menjadi penyebab terjadinya peningkatan hasil belajar siswa dan diikuti dengan keterampilan sosial siswa.

Kualitas pembelajaran guru pada setiap pertemuan menunjukkan peningkatan 
yang memuaskan, siswa semakin faham dan menyukai model pembelajaran berbasis kemampuan generik yang ditawarkan oleh guru, dengan pola belajar berkelompok memungkinkan siswa untuk belajar lebih banyak dan giat, karena selain pengetahuan melalui penjelasan guru mengenai tujuan yang ingin dicapai dalam setiap kali memulai pembelajaran, siswa sudah mempunyai wawasan tentang menulis cerpen yang dipelajari selama pembelajaran berlangsung. Cara belajar seperti ini dapat memperkaya siswa melalui diskusi atau tanya jawab selagi mereka belajar berkelompok. Karena memulai proses diskusi dengan teman sebaya siswa akan mampu menyerap lebih cepat dan banyak bila dibandingkan dengan pada saat mereka berhadapan langsung dengan guru. Di samping itu juga siswa memiliki kesempatan yang memadai untuk mematangkan dan memperkaya pengetahuan, siswa juga berkesempatan untuk mengembangkan dan melatih seperangkat sikap dan keterampian sosialnya.

Pola interaksi dalam kelompok sebagaimana yang terjadi pada pengembangan model kemampuan generik dalam penelitian ini, menjadikan siswa bukan saja sebagai dirinya sendiri, tetapi juga sebagai satu kesatuan dari kelompoknya, sehingga belajar dengan cara berkelompok akan membantu siswa untuk menumbuhkembangkan hubungan dan kebersamaan di antara mereka yang bermuara kepada peningkatan pengertian dan pemahaman siswa terhadap materi menulis cerpen dan pada akhirnya akan meningkatkan hasil belajar siswa.

Setelah desain pembelajaran kemampuan generik MKG 1 disusun, maka perencanaan tersebut diimplementasikan dalam proses pembelajaran di kelas dan MKG 1 terdapat kelemahan seperti yang sudah dijelaskan sebelumnya, setelah diimplementasikan dan dihasilkan produk lalu dievaluasai maka disempurnakan dengan lahirnya MKG 2 kemudian diuji coba terbatas.

Pada uji coba terbatas, dalam berdiskusi siswa telah menunjukkan aktivitas yang meningkat serta memperoleh nilai yang meyakinkan dan meningkat dari secara signifikan dari MKG 1 kemudian MKG 2.

\section{f. Peningkatan kemampuan menulis cerpen siswa dengan model pembelajaran berbasis kemampuan generik \\ Dari uji coba terbatas terlihat ada} peningkatan hasil belajar siswa dan kegiatan siswa, di mana siswa menunjukkan keterlibatannya dalam bekerja kelompok dengan teman sebayanya dalam kegiatan pembelajaran seperti sudah berani untuk bertanya atau menjawab pertanyaan yang diberikan guru atau temannya sendiri, serta berani dalam mengeluarkan saran, pendapat, juga berani berkomunikasi secara baik dan benar.

Selama kegiatan pembelajaran berlangsung dilakukan monitoring, observasi, dan revisi, dan diakhiri dengan kegiatan postes kemudian dilanjutkan dengan kegiatan diskusi.

Evaluasi pembelajaran menulis cerpen dengan model kemampuan generik

Evaluasi pembelajaran menulis cerpen dengan model kemampuan generik dilakukan dengan mengambil hasil kerja siswa yaitu berupa hasil cerpen yang belum menggunakan model kemampuan generik, MKG 1 dan MKG 2, saat pembelajaran berlangsung ada penilaian proses, baik terhadap kelompok maupun individu. Selanjutnya diambil lagi hasil tugas kelompok dan individu yang menggunakan model kemampuan generik untuk mengetahui ketercapaian hasil belajar yang didapat siswa. 
Evaluasi proses dilakukan pada saat pembelajaran berlangsung terutama pada saat siswa terlibat dalam pembelajaran dengan model kemampuan generik 1 dan MKG 2. Evaluasi proses ini dilakukan melalui lembar observasi seperti pada lampiran dengan kriteria (1) Siswa terlihat aktif dalam mengerjakan tugas yang telah diberikan baik secara kelompok maupun individu. (2) Siswa baik secara individu maupun kelompok aktif merespon pembelajaran. (3) Guru merupakan fasilitator, yang mengkondisikan siswa termotivasi untuk menyelesaikan kegiatan pembelajaran dengan giat.

Dengan model pembelajaran kemampuan generik suasana pembelajaran lebih teratur, siswa lebih berani mengemukakan gagasannya dan argumentasi atas pertanyaan yang diberikan oleh guru maupun temannya pada saat mempresentasikan hasil kerja kelompoknya di depan kelas.

Dari hasil uji coba terbatas, terlihat perbedaan antara sebelum menggunakan model kemampuan generik, sesudah menggunakan MKG 1 dan sesudah menggunakan MKG 2, motivasi dalam belajar semakin tinggi, semangat untuk menemukan dan mengemukakan sesuatu yang baru selalu berkobar, sikap demokratis, berpikir kritis dan logis serta kemampuan menggalang kerja sama siswa menjadi lebih baik. Sehingga tujuan dari pembelajaran dapat tercapai sesuai dengan yang diharapkan.

\section{Penutup}

Simpulan dalam penelitian ini:

1. Pemilihan pengembangan model pembelajaran yang tepat dapat merangsang siswa dalam mengembangkan aktivitas dan kreativitas.

2. Pembelajaran dengan pengembangan model kemampuan generik telah berhasil meningkatkan kemampuan menulis cerpen siswa kelas XI IPA 2 MAN 1 Mataram.

3. Menumbuhkan sikap positif siswa dalam hal metode pembelajaran, materi pembelajaran, keaktifan dan motivasi dalam pembelajaran.

4. Model pembelajaran yang dihasilkan lebih unggul dalam meningkatkan kuantitas dan kualitas cerpen siswa.

\section{Daftar Pustaka}

Agus Nuryatin. 2008. Pembelajaran menulis Karya Sastra Cerita Pendek: Memberi Bekal Life Skill Kepada Siswa. Batu: Hiski

Arikunto, Suharsimi. 2002. Metodologi Penelitian. PT. Rineka Cipta: Jakarta.

Arikunto, Suharsimi. 2006. Prosedur Penelitian: Suatu Pendekatan Praktik (Edisi Revisi). Jakarta: PT Rineka Cipta.

Australian National Training Authority. 2003. Defining Generic Skills. NCVER: Australia. Tersedia:

Carino, Peter. 1991. Basic Writing a First Cause. Newyork: Harper Colius Publisher.

Faruk. 2003. Pengantar Sosiologi Sastra Edisi Revisi. Pustaka Pelajar: Jogjakarta.

Hadi, Sutrinso. 2000. Metodologi Penelitian. Yayasan Fakultas Psikologi UGM: Yogyakarta.

Menakertrans. 2009. Keputusan Menteri Tenaga Kerja dan Transmigrasi Republik Indonesia Nomor Kep.57/MEN/III/2009 tentang Penetapan Standar Kompetensi Kerja Nasional Indonesia Sektor Pariwisata 
140|Mabasan, Vol. 9 No.2, Juli-Desember 2015: 126-141

Bidang Kepemanduan Wisata.

Tersedia:

http//blog.uad.ac.id/sayuti/2010/05/22/ketera

mpilan-generik-di-smk proposal-

untuk-membangun- karakter-

siswa-smk/

Nurgiyantoro, Burhan. 2001. Penilaian dalam Pengajaran bahasa dan Sastra. Yogyakarta: Gadjah Mada Universitas Press.

Reynolds, Chris dan Tony Mackay. 1997. Generic Skills (Key Competencies) in Australia - the Way of the Future or a track into the Never Never?. University of York

Sugiyono. 2008. Metode Penelitian Kuantitatif, Kualitatif dan $R \& D$. CV. ALFABETA: Bandung. 
Pengembangan Model Kemampuan Generik...(Rabiyatul Adawiyah \& Syukrina Rachmawati)|141 